
ДЕЯКІ АСПЕКТИ НЕГАТИВНОГО ВПЛИВУ СЮЖЕТІВ ПРО НАДЗВИЧАЙНІ
СИТУАЦІЇ НА КОГНІТИВНІ ТА ЕМОЦІЙНІ ПРОЦЕСИ ЛЮДИНИ

\title{
SOME ASPECTS OF THE NEGATIVE IMPACT OF EMERGENCY STORIES ON A PERSON'S COGNITIVE AND EMOTIONAL PROCESSES
}

\begin{abstract}
y статmі розглянуто проблему негативного впливу сюжетів про надзвичайні ситуації на когнітивні та емоційні процеси людини. Репортажі про надзвичайні ситуації приковують увагу мільйонів людей, а сучасні засоби масової інфрормації надзвичайно живо та яскраво викладають репортажі з місця подій, викликаючи у глядачів відчуття того, що вони переглядають їх у реальному часі. Проаналізовано результати перегляду таких відеосюжетів, розкрито процеси та механізми, що відбуваються з глядачами у процесі перегляду подібних сюжетів. Часто виникає ситуація, коли людина розуміє, чому саме виявилася свідком, але при цьому вірить, що не може вплинути на ситуацію, таким чином, виникає буденний шок. У людини, що стала свідком насильства та руйнування, відбувається руйнування екзистенціального уявлення про світ, такі ситуації вщент розбивають базову, неусвідомлювану довіру до світу, його устрій, розуміння того, що людина контролює світ і своє життя. Коли ці уявлення піддаються критиці, людина втрачає віру у те, що вона здатна впливати на хід подій, опиняється в стані «пасивного глядача» свого життя. у статmі викладено напрацювання вчених, що займались дослідженням впливу сюжетів про надзвичайні ситуації на різні сорери особистості. Також важливе місце серед аналізу теоретичного матеріалу посідає проблема невисловлених емоцій та переживань. Продемонстровано позитивну кореляцію психологічного та соматичного стану людини з тим, чи обговорювала вона пережиті травмуючі події. Проведене автором дослідження щодо впливу сюжетів про надзвичайні ситуації на емоційні та когнітивні процеси людини зосереджене на виявленні змін у таких когнітивних процесах, як пам'ять, увага, логічне мислення та емоційні переживання (почуття провини, реактивна та особистісна тривожність, самопочуття, активність та настрій). Ключові слова: надзвичайні ситуації, руй-
нування, катастрофа, емоційні процеси,
когнітивні процеси, ЗмІ, переживання,
буденний шок.

The article deals with the problem of the negative impact of stories about emergency situations on a person's cognitive and emotional processes. Emergency reports attract the attention of millions of people, and modern media extremely vividly and vividly present reports from the scene, thereby causing viewers to feel that they are viewing them in real time. The results of viewing such videos were analyzed, and the processes and mechanisms that occur with viewers in the process of viewing such stories were revealed. Among other things, there is often a situation when a person understands exactly why he was a witness, but at the same time believes that he cannot influence the situation, thus, there is an ordinary shock. In a person who has witnessed violence and destruction, the existential idea of the world is being destroyed; such situations shatter the basic, unconscious trust in the world, its structure, that a person controls the world and his life. When these ideas are criticized, a person loses faith that he is able to influence the course of events, finds himself in a state of "passive viewer" of his life. The article describes the best practices of scientists who studied the impact of stories about emergency situations on various areas of the individual. Also, an important place among the analysis of theoretical material is occupied by the problem of unspoken emotions and experiences. It shows a positive correlation between the psychological and somatic state of a person and whether they discussed the traumatic events they experienced. The author's research on the impact of emergency stories on a person's emotional and cognitive processes focuses on identifying changes in cognitive processes such as memory, attention, logical thinking, and emotional experiences - guilt, reactive and personal anxiety, well-being, activity, and mood.

Key words: emergency situations, destruction, catastrophe, emotional processes, cognitive processes, media, experiences, everyday shock.
Національний університет

цивільного захисту України 
ків 3MI, аналізуються проблемі організації діяльності в умовах надзвичайних ситуацій. Досвід психіатрії катастроф свідчить про те, що у виникненні психічних порушень провідна роль належить не самій НC, а тому, наскільки людина як особистість сприймає, переживає та інтерпретує цю подію [1, с. 13]. За результатами досліджень Р. Пацлафа, викладених у його праці «Застиглий погляд», знання, отримані через 3MІ, були забуті, відповідно до вже відомих кривих забування, але емоційні переживання, що були викликані масмедіа, залишилися в первісному вигляді [5, с. 28]. Звичайно, насильство розглядається як драма з двома ролями, а саме кривдника і жертви. Насправді, здебільшого є ще третя роль - спостерігача, якого Кейте Вайнгартен називає свідком [8, с. 43]. Кейте Вайнгартен вводить поняття «буденний шок» для визначення процесів, що відбуваються з людьми, які спостерігають як безпосередньо, так і через засоби масової інформації ситуації насильства та руйнування [6, с. 62]. Вчені виділяють три такі рівні можливого впливу медіанасильства, як поведінковий, афективний та когнітивний. До поведінкових проявів належать такі процеси, як катарсис, збудження, дизингібація (розторможування) та десенсибілізація.

Механізм катарсису дає можливість людині безпечно виводити свої агресивні та руйнівні імпульси посередництвом перегляду чи представлення в уяві сюжетів насильства та жорстокості.

Під час перегляду агресивних, насильницьких чи жахітливих (також у цю групу входять комічні та відверті сюжети) людина, що споглядає такі сцени, почувається емоційно збудженою та має відповідні прояви на рівні фізіології. Отже, реакція такої людини стає більш емоційною та агресивною, особливо незабаром після перегляду.

Механізм дизингібіції проявляється в тому, що чим більше телеглядачі звикають до агресії та насильства на екранах телевізорів (насамперед, це стосується санкціонованого насильства), тим менш ефективною $є$ дія соціальних санкцій для того, щоб стримувати подібні імпульси.

Імітація - це механізм дії, заснований на припущенні, що побачені на телеекрані моделі поведінки глядачі застосовують і відтворюють у реальному житті.

Десенсибілізація передбачає, що під час регулярного споглядання сцен насильства глядачі втрачають чутливість до насильства та жорстокості на екрані.

Когнітивні прояви передбачають таке. М. Вобер і Б. Гантер виявили, що особливості світосприйняття глядача стосуються скоріше характеру програм, ніж часу, проведеному перед екраном. Дані цього дослідження свід- чать про те, що глядачі вибирають певні типи програм, які узгоджуються з їх світосприйняттям або закріплюють його [9].

Постановка завдання. Метою статті $€$ аналіз та представлення результатів емпіричного дослідження негативного впливу сюжетів про надзвичайні ситуації на когнітивні та емоційні процеси людини.

Виклад основного матеріалу дослідження. Визначення негативних впливів від перегляду сюжетів про надзвичайні ситуації на когнітивні та емоційні процеси людини проводилось за такими методиками, як шкала оцінки рівня реактивної та особистісної тривожності (Ч.Д. Спілберг, Ю.Л. Ханін) [3, с. 30]; методика «Визначення концентрації уваги» [4, с. 130]; методика «Сприйманий індекс провини, PGI. Тест на почуття провини» (Perceived Guild Index) [4]; методика «Закономірності числового ряду» [3, с. 219]; методика «Заучування десяти слів» А.Р. Лурія [7, с. 42]; методика САН (самопочуття, активність, настрій) [7, с. 83]. У дослідженні взяли участь 34 людини віком від 23 до 47 років, серед яких 55,8\% жінок і 44,2\% чоловіків. Для того щоб визначити вплив негативних повідомлень, дослідження проводилось у декілька таких етапів:

1) тестування за всіма представленими методиками; ації

2) перегляд сюжетів про надзвичайні ситу-

3) повторне тестування для визначення динаміки змін.

На першому етапі дослідження були отримані дані про рівень реактивної та особистісної тривожності досліджуваних (табл. 1).

\section{Розподіл досліджуваних за рівнем реактивної тривожності} Таблиця 1

\begin{tabular}{|l|c|}
\hline \multicolumn{1}{|c|}{$\begin{array}{c}\text { Рівень реактивної } \\
\text { тривожності }\end{array}$} & $\begin{array}{c}\text { Кількість } \\
\text { досліджуваних }\end{array}$ \\
\hline До 30 (низька) & $70,5 \%$ \\
\hline $\begin{array}{l}31-45 \text { (помірна } \\
\text { тривожність) }\end{array}$ & $26,5 \%$ \\
\hline 46 і більше (висока) & $3 \%$ \\
\hline
\end{tabular}

Як бачимо з даних, що наведені у табл. 1, у досліджуваних превалює низький рівень реактивної тривожності. Так, помірний рівень реактивної тривожності було виявлено лише у $26,5 \%$ опитаних, а 3\% мали високий рівень реактивної тривожності. В ході дослідження рівня особистісної тривожності дані розподілилися таким чином: низький рівень тривожності мали лише 6\% опитаних, основна кількість досліджуваних $(64,7 \%)$ виявила помірний рівень особистісної тривожності, а високий рівень було зафіксовано у $29,3 \%$ респондентів (табл. 2). 
Розподіл досліджуваних за рівнем

Таблиця 2 особистісної тривожності

\begin{tabular}{|l|c|}
\hline \multicolumn{1}{|c|}{$\begin{array}{c}\text { Рівень особистісної } \\
\text { тривожності }\end{array}$} & $\begin{array}{c}\text { Кількість } \\
\text { досліджуваних }\end{array}$ \\
\hline До 30 (низька) & $6 \%$ \\
\hline $\begin{array}{l}31-45 \text { (помірна } \\
\text { тривожність) }\end{array}$ & $64,7 \%$ \\
\hline 46 і більше (висока) & $29,3 \%$ \\
\hline
\end{tabular}

Методика (тест на почуття провини) використовується для вимірювання почуття провини як стану на даний момент і як риси характеру, яка проявляє себе зазвичай, найчастіше. Аналіз результатів методики сприйманого індексу провини виявив наявність почуття провини у 8,8\% досліджуваних, відповідно, 91,2\% не мали почуття провини.

Проведення методики САН дало розуміння рівня трьох змінних, а саме самопочуття, активності та настрою. Досліджувані розподілились на три групи. Так, у першої групи рівень самопочуття нижче нормального за методикою, таких було 47\%, у другої групи самопочуття відповідало нормі, їх сума складає 38,2\%, показник умовно виділеної третьої групи, у якої рівень самопочуття вище норми, складав $14,8 \%$ опитаних. За рівнем активності 38,2\% досліджуваних відзначили низький рівень активності, а респондентів, дані яких відповідають нормі за методикою, виявилось $61,8 \%$. Аналіз показників настрою у $29,4 \%$ опитаних відповідає нормі, настрій вище норми показали 23,6\% опитаних, низькі показники рівня настрою відзначили 47\% від генеральної сукупності (табл. 3).

Досліджуючи вплив негативної інформації на когнітивні процеси особистості, а саме вплив на здатність людини до логічного мислення, ми застосовували методику закономірності числового ряду. Досліджуваним було надано 7 рядків з числовими закономірностями, де їм необхідно було зрозуміти закономірність і заповнити 13 відсутніх чисел. Всі закономірності були розкриті $11,7 \%$ опитаних, $20,6 \%$ опитаних правильно відзначили $92,3 \%$ чисел, 23,6\% респондентів правильно відзначили 76,9\% чисел, $61,5 \%$ і 46,2\% відповідей розподілилися між $11,7 \%$ досліджуваних. $15,4 \%$ та $30,8 \%$ правильних закономірності вказали по 5,9\% відповідно, ще 3\% відзначили 23,1\% правильних чисел. Відмовились проходити тестування за методикою 5,9\% опитуваних (табл. 4).

Таблиця 4

Розподіл досліджуваних за методикою закономірності числового ряду

\begin{tabular}{|c|c|}
\hline $\begin{array}{c}\text { Кількість правильних } \\
\text { відповідей }\end{array}$ & $\begin{array}{c}\text { Кількість } \\
\text { досліджуваних }\end{array}$ \\
\hline 0 & $5,9 \%$ \\
\hline 2 & $5,9 \%$ \\
\hline 3 & $3 \%$ \\
\hline 4 & $5,9 \%$ \\
\hline 6 & $11,7 \%$ \\
\hline 8 & $11,7 \%$ \\
\hline 10 & $23,6 \%$ \\
\hline 12 & $20,6 \%$ \\
\hline 13 & $11,7 \%$ \\
\hline
\end{tabular}

Для визначення впливу сюжетів про надзвичайні ситуації на властивості уваги досліджуваним було запропоновано методику «Властивості концентрації уваги», в ході якої вони мали віднайти якомога більше чисел по наростаючій від 1 до 99. На проходження тесту досліджувані мали п'ять хвилин. За результатами методики виявлено, що 11,8\% досліджуваних знайшли від 1 до 10 чисел, 67,5\% відшукали від 11 до 20 чисел, а 20,7\% респондентів знайшли більше 21 числа (табл. 5).

Розподіл респондентів за методикою "Властивості концентрації уваги"

\begin{tabular}{|c|c|}
\hline $\begin{array}{c}\text { Кількість знайдених } \\
\text { чисел }\end{array}$ & $\begin{array}{c}\text { Кількість } \\
\text { досліджуваних }\end{array}$ \\
\hline до 10 & $11,8 \%$ \\
\hline $11-20$ & $67,5 \%$ \\
\hline 21 і більше & $20,7 \%$ \\
\hline
\end{tabular}

Продовжуючи дослідження впливу на когнітивні процеси особистості, ми запропонували досліджуваним методику А.Р. Лурія. Дослідження пам'яті за цією методикою виявило, що норму запам'ятовування слів показали 29,4\% (10 слів) і 20,6\% (9 слів), інші респонденти запам'ятали менше слів і розподілились

Розподіл досліджуваних за рівнем самопочуття, активності, настрою

\begin{tabular}{|l|c|c|c|}
\hline & Самопочуття & Активність & Настрій \\
\hline Нижче норми & $47 \%$ & $38,2 \%$ & $47 \%$ \\
\hline Норма & $38,2 \%$ & $61,8 \%$ & $29,4 \%$ \\
\hline Вище норми & $14,8 \%$ & 0 & $23,6 \%$ \\
\hline
\end{tabular}


на 32,3\% (8 слів), 14,7\% (7 слів), а 3\% запам'ятали лише 6 слів із 10 названих за методикою (табл. 6).

Таблиця 6

Розподіл досліджуваних за рівнем довготривалої пам'яті

\begin{tabular}{|l|c|}
\hline $\begin{array}{c}\text { Кількість } \\
\text { запам'ятованих слів у } \\
\text { довготривалій пам'яті }\end{array}$ & $\begin{array}{c}\text { Кількість } \\
\text { досліджуваних }\end{array}$ \\
\hline 10 слів & $29,4 \%$ \\
\hline 9 слів & $20,6 \%$ \\
\hline 8 слів & $32,3 \%$ \\
\hline 7 слів & $14,7 \%$ \\
\hline 6 слів & $3 \%$ \\
\hline
\end{tabular}

На другому етапі досліджуваним був продемонстрований відеоряд про надзвичайні ситуації, що включав різнопланові сюжети про терористичні акти, пожежі, землетруси, повені, вибухи та цунамі. Загальний час перегляду відеоряду становить 18 хвилин 30 секунд.

Третім етапом дослідження $€$ повторне тестування для визначення впливу перегляду сюжетів про надзвичайні ситуації на когнітивні та емоційні процеси людини. Для цього тестування проходило одразу після показу відеоряду. Під час повторного тестування методику «Шкала оцінки рівня реактивної та особистісної тривожності» досліджувані проходили лише щодо реактивної тривожності.

\section{Розподіл досліджуваних за рівнем реактивної тривожності (повторне тестування)}

\begin{tabular}{|l|c|}
\hline \multicolumn{1}{|c|}{$\begin{array}{c}\text { Рівень реактивної } \\
\text { тривожності }\end{array}$} & $\begin{array}{c}\text { Кількість } \\
\text { досліджуваних }\end{array}$ \\
\hline До 30 (низька) & $73,5 \%$ \\
\hline $\begin{array}{l}31-45 \text { (помірна } \\
\text { тривожність) }\end{array}$ & $20,5 \%$ \\
\hline 46 і більше (висока) & $6 \%$ \\
\hline
\end{tabular}

Як свідчать дані, наведені у табл. 7, 73,5\% досліджуваних мають низький рівень реактивної тривожності, у 20,5\% опитаних рівень тривожності характеризується як помірний, а високий її рівень зафіксовано у 6\% опитаних. Після порівняння даних, отриманих у ході другого тестування, з даними першого тестування відзначаються деякі зміни в рівні тривожності респондентів. У частини досліджуваних $(20,6 \%)$ тривожність після перегляду сюжетів про надзвичайні ситуації стала вищою, ніж була від самого початку дослідження. Також фіксується $14,7 \%$ респондентів, у яких реактивна тривожність знизилась після повторного тестування.
Повторне проведення методики сприйманого індексу провини не виявило збільшення почуття провини у досліджуваних, навпаки, в 5,9\% опитаних почуття провини знизилось до нормального рівня.

Проведення методики САН після перегляду відеоряду вказує на незначні зміни у показниках активності та настрою. Показники категорії «Самопочуття» залишились такими ж, якими вони були після першого тестування. Проаналізувавши категорію «Активність», 35,3\% опитаних відзначили низький рівень активності. Показники інших 61,8\% респондентів відповідають нормі. Порівняння даних дослідження за категорією «Активність» показує, що 5,9\% опитаних відзначили підвищення показників після перегляду відеоряду. У категорії «Настрій» результати відповідей 29,4\% опитаних відповідають нормі, настрій вище норми показали $20,6 \%$ опитаних. Низькі показники рівня настрою відзначили 50\% усіх опитаних (табл. 8).

У методиці закономірності числового ряду для другого тестування були змінені закономірності на такі, які досліджувані раніше не бачили. В методиці розташовано 7 рядків із числовими закономірностями, де необхідно заповнити 14 відсутніх чисел. Від загальної кількості невідомих чисел 100\% закономірностей були розкриті 11,7\% опитаних, по 3\% досліджуваних правильно відзначили 92,8\%, 78,6\%, 21,4\% і 14,3\% чисел відповідно, 29,5\% респондентів правильно відзначили 85,7\% чисел. 42,8\% правильних відповідей надали $14,7 \%$ респондентів, 5,9\% відзначили 28,5\% правильних закономірностей. Відмовились проходити тестування за методикою 8,8\% опитуваних.

Значних змін під час повторного проходження методики закономірності числового ряду не відзначається. Під час повторного тестування за методикою «Властивості концентрації уваги» показники уваги розподілились таким чином: 20,7\% досліджуваних знайшли від 1 до 10 чисел, 53\% відшукали від 11 до 20 чисел, a 26,3\% респондентів знайшли більше 21 числа. Результати повторного тестування показують, що в $11,7 \%$ досліджуваних погіршились показники уваги, одночасно у 5,9\% опитаних властивості уваги покращились.

Останньою методикою у повторному тестуванні $€$ методика на визначення властивостей пам'яті А.P. Лурія. Згідно з даними, отриманими під час повторного тестування, норму запам'ятовування слів показали $35,5 \%$ (10 слів) і 26,3\% (9 слів), інші респонденти запам'ятали менше слів і розподілились на 29,4\% (8 слів), 6\% (7 слів), а 3\% запам'ятали лише 6 слів із 10 названих за методикою. Такі показники свідчать про незначні коливання властивостей пам'яті між першим та другим тестуваннями (табл. 9). 
Порівняння розподілу досліджуваних за рівнем самопочуття, активності, настрою у першому та другому тестуваннях

\begin{tabular}{|l|c|c|c|c|c|c|}
\hline \multirow{2}{*}{} & \multicolumn{2}{|c|}{ Самопочття } & \multicolumn{2}{c|}{ Активність } & \multicolumn{2}{c|}{ Настрій } \\
\cline { 2 - 7 } & $\mathbf{1}$ тест & $\mathbf{2}$ тест & $\mathbf{1}$ тест & $\mathbf{2 ~ т е с т ~}$ & $\mathbf{1}$ тест & $\mathbf{2}$ тест \\
\hline Нижче норми & $47 \%$ & $47 \%$ & $38,2 \%$ & $35,3 \%$ & $47 \%$ & $50 \%$ \\
\hline Норма & $38,2 \%$ & $38,2 \%$ & $61,8 \%$ & $64,7 \%$ & $29,4 \%$ & $29,4 \%$ \\
\hline Вище норми & $14,8 \%$ & $14,8 \%$ & 0 & 0 & $23,6 \%$ & $20,6 \%$ \\
\hline
\end{tabular}

Порівняння розподілу досліджуваних за рівнем довготривалої пам'яті

\begin{tabular}{|l|c|c|}
\hline $\begin{array}{c}\text { Кількість запам'ятованих слів } \\
\text { у довготривалій пам'яті }\end{array}$ & $\begin{array}{c}\text { Кількість досліджуваних } \\
\text { (1 тестування) }\end{array}$ & $\begin{array}{c}\text { Кількість досліджуваних } \\
\text { (2 тестування) }\end{array}$ \\
\hline 10 слів & $29,4 \%$ & $35,5 \%$ \\
\hline 9 слів & $20,6 \%$ & $26,3 \%$ \\
\hline 8 слів & $32,3 \%$ & $29,4 \%$ \\
\hline 7 слів & $14,7 \%$ & $6 \%$ \\
\hline 6 слів & $3 \%$ & $3 \%$ \\
\hline
\end{tabular}

Висновки з проведеного дослідження. Отже, припущення про те, що перегляд сюжетів про надзвичайні ситуації має негативний вплив на когнітивні та емоційні процеси людини, не підтвердилось, але й не спростувалося. Найпомітніші зміни відбулися в емоційній сфері досліджуваних, а саме позначились на рівні тривожності досліджуваних. На когнітивні процеси перегляд відеоряду про надзвичайні ситуації суттєво не впливає. Такий результат дослідження свідчить про наявність механізмів десенсибілізації.

Подальше вивчення проблеми потребує лонгітюдних методів дослідження для визначення позитивної кореляції між переглядом сюжетів про надзвичайні ситуації та перспективою їх впливу на емоційні та когнітивні процеси дорослої людини.

\section{ЛITEPATУРA:}

1. Бервенова О.В. Компенсаторные ресурсы средств массовой инсрормации в чрезвычайных ситуациях : дисс. ... канд. полит. наук / РАГС. Москва, 2007. $136 \mathrm{c}$.

2. Карелин А.А. Большая энциклопедия психологических тестов. Москва : Эксмо, 2007. 416 с.
3. Методика «Воспринимаемый индекс вины, PGI. Тест на чувство вины». (Perceived Guilt Index). URL: https://psycabi.net/testy/518-metodikavosprinimaemyj-indeks-viny-pgi-test-na-chuvstvo-vinyperceived-guilt-index (дата звернення: 12.04.2021).

4. Неурова А.Б., Капінус О.С., Грицевич Т.Л. Діагностика індивідуально-психологічних властивостей особистості : навчально-методичний посібник. Львів : HACB, 2016. 181 c.

5. Пацлаф Р. Застывший взгляд. Москва : Evidentis, 2003. $224 \mathrm{c}$.

6. Проблеми екстремальної та кризової психології : збірник наукових праць. Вип. 12. Ч. ІІ. Харків : НУЦЗУ, 2012. 192 с.

7. Психологическая диагностика ссрер личности: лабораторный практикум / авт.-сост. Ю.Е. Водяха. Екатеринбург : Уральский государственный педагогический университет, 2018. 219 с.

8. Weingarten K. Common Shock: Witnessing Violence Every Day - How We Are Harmed, How We Can Heal. Weingarten, New York : Dutton, 2003. 231 p.

9. Wober M., Gunter B. British Journal of Social Psychology. Television and personal threat: fact or artifact? A British survey. 1982. P. 239-247. URL: https://bpspsychub.onlinelibrary.wiley.com/ doi/abs/10.1111/j.2044-8309.1982.tb00545.x (дата звернення: 12.04.2021). 